\title{
DON QUIJOTE, PASAMONTE Y LA PICARESCA DE SOSLAYO
}

\author{
Valentín Núñez Rivera \\ Universidad de Huelva
}

\begin{abstract}
In the adventure of the Galeotes (I,22), Cervantes builds up one of the most highly metaliterary episodes in Don Quixote. In it Cervantes holds an ambivalent position about certain aspects of the poetics of the picaresque novel, namely the autobiographical perspective and vital determinism, both of them linked to the problem of verisimilitude. Cervantes casts some mocking winks as Guzmán de Alfarache, though he seems to pay homage to Lazarillo de Tormes, among other reasons for the importance granted to the addressee in picaresque discourse, a category that Cervantes does accept in opposition to the notion of picaresque novel.
\end{abstract}

\author{
No te metas en dibu- \\ ni en saber vidas aje- \\ que en lo que no va ni vie- \\ pasar de largo es cordu-
}

Con la lectura de I, XXII se llega a la conclusión evidente de que el capítulo ocupa un lugar de verdadero realce en el Quijote de 1605. Esta situación privilegiada se refiere, sobre todo, al valor intrínseco de la aventura de los galeotes, ya que con ella comienza un repliegue progresivo del héroe, inmerso cada vez más en un mundo literaturizado que lo confunde y apoca. Asimismo, se manifiesta como contrapunto de los hechos precedentes y más, si cabe, de lo que habrá de acontecer en adelante. Lo primero que salta a la vista es la mención del cronista arábigo, Cide Hamete Benengeli, nada más empezar: "Cuenta Cide Hamete Benengeli, autor arábigo y manchego, en esta gravísima, altisonante, mínima, dulce e imaginada historia, que después que entre el famoso don Quijote de la Mancha y Sancho Panza, su escudero, pasaron aquellas razones que en el fin del capítulo veinte y uno quedan referidas..." (235) $)^{1}$. Este procedimiento pretende subrayar la existencia de un narrador en tercera persona de las hazañas de don Quijote, algo muy importante, como iremos comprobando, en contraste con otras posibilidades narrativas. Repárese, por supuesto, en un dato más. En el capítulo XV, inicio de la Tercera Parte, se produce un comienzo del todo paralelo ("Cuenta el sabio Cide Hamete Benengeli que así como don Quijote...., 159), tal vez debido aquí a la necesidad de establecer un hito en el decurso de la narración. Algo que guarda plena coherencia con la aparición de Cide Hamete en el capítulo IX, apertura, por su lado, de la Segunda parte de la historia.

Igualmente, el capítulo anterior al de los galeotes, la alta aventura y rica ganancia del yelmo de Mambrino, obtiene una proyección significativa de primera magnitud, por medio de varias propuestas de sentido. Primero, porque se cierra un tipo de aventuras (de XVIII a XXII) de naturaleza incierta, con intervenciones que tanto don Quijote como el lector

${ }^{1}$ Todas las citas del Quijote van por la ed. dirigida por F. Rico (Barcelona, Crítica/Instituto Cervantes, 1998). 
tienen que interpretar de su cosecha. En definitiva, el propio yelmo, baciyelmo a la postre, se convertirá en cifra de la realidad oscilante en la que se desenvuelve la novela toda ${ }^{2}$. Por lo demás, el robo del yelmo producirá consecuencias narrativas que llegan a término en los capítulos XLIV-XLV, cuando reaparezca el barbero damnificado en la venta de Palomeque el zurdo. Algo parecido, pero de mayor alcance incluso, habrá de ocurrir con el personaje de Ginés de Pasamonte, el más notorio de entre los doce forzados, cuya pervivencia en la novela alcanza al Quijote de 1615. En primera instancia, el miedo de don Quijote, y especialmente de Sancho, por la represalia de la Santa Hermandad como respuesta de su acción liberadora ${ }^{3}$, será el motivo para que en I, XXIII se internen en la sierra ${ }^{4}$. Y este mismo sentimiento se deja notar en los capítulos I, XLV y XLVI. Una intentona de hacer el bien que le será pagada a don Quijote con la moneda del desagradecimiento ${ }^{5}$.

Tras ese núcleo de aventuras inciertas, el encuentro con los galeotes proporciona una especie de escollo, aislado en su singularidad. Y es que el ingenioso hidalgo se enfrenta con los prisioneros siendo perfectamente consciente de la realidad que se le presenta ante los ojos. Y así, la interpreta como un hecho relativo al sistema de justicia imperante en la época ${ }^{6}$. Este internarse en la vida podría parecer a primera vista una anomalía con respecto al procedimiento cervantino de intercalar retazos literarios provenientes de otros géneros, como el pastoril de Crisóstomo y Marcela (I, XII-XV), o el sentimental de Cardenio, que se desarrollará en breve, a partir de I, XXIII ${ }^{7}$. Pero no resulta ser así de ningún modo, porque en este capítulo Cervantes no parte de la realidad histórica sin más, sino que hace reflexionar a sus personajes acerca de la fórmula literaria más apegada al modo de vida contemporáneo, esto es la llamada novela picaresca. En realidad, el capítulo XXII es uno de los trechos más metaliterarios de toda la obra -metapicaresco, para ser más exactos-, equiparable en este sentido al donoso escrutinio en la librería de don Quijote, las disquisiciones antes de la lectura del Curioso impertinente (I, XXXII), la discusión en I,

\footnotetext{
${ }^{2}$ A. Castro, El pensamiento de Cervantes, Barcelona/Madrid, Noguer, 1980 (ed. ampliada, con notas del autor y de J. Rodríguez-Puértolas, pp. 82 y ss.). Existe reedición en Madrid, Trotta, 2002. Añádase el planteamiento de los problemas epistemológicos en la cosmovisión de don Quijote de Juan Bautista Avalle-Arce, "Conocimiento y vida en Cervantes" en Nuevos deslindes cervantinos, Barcelona, Ariel, 1975, especialmente pp. 17-58.

3 "Entristecióse mucho Sancho deste suceso, porque se le representó que los que iban huyendo habían de dar noticia del caso a la Santa Hermandad, la cual a campana herida saldría a buscar los delincuentes, y así se lo dijo a su amo, y le rogó que luego de allí se partiesen y se emboscasen en la sierra, que estaba cerca”, 245-246.

${ }^{4}$ Queda muy patente, por ejemplo en I, XXIX (pp. 344-345).

${ }^{5}$ Sancho comenta al respecto: "La aventura sin ventura de los galeotes" (II, IV). Cide Hamete dice, igualmente, que la liberación fue "beneficio que después le fue mal agradecido y peor pagado de aquella gente maligna y mal acostumbrada" (II, XXVII).

${ }^{6}$ Sobre este particular, relativo a la trascendencia histórica del capítulo, no trataré en este lugar. Váyase para una revisión de última hora a J. Canavaggio, "Don Quijote entre libro y mito: la aventura de los galeotes" en Mitos literarios españoles, ed. J. María Díez Borque, Madrid, Fundación Carolina, 2004, pp. 106-126, relacionándolo con su anterior, "Burlas y veras en la aventura de los galeotes: Nueva reflexión sobre un episodio del Quijote", Anales Cervantinos, XVIII (1979-80), pp. 25-33.

${ }^{7}$ Para una interpretación contextualizada de ambos episodios véase: V. Núñez Rivera, "A ratos en la Arcadia. Variaciones cervantinas sobre la utopía pastoril (El Quijote, 1605-1615)" en Utopía. Los espacios imposibles, ed. R. García, E. Navarro y V. Núñez, Frankfurt, Peter Lang, 2003, pp. 117-133 y "La historia de Cardenio desde la poética sentimental" en Cervantes y su mundo, II, ed. K. Reichenberger y D. Fernández Morera, Kassel, Edition Reichenberger, 2005, pp. 341-367.
} 
XLVII sobre los libros de caballerías o en XLVIII sobre la comedia nueva. Lo que se discute aquí son nada más y nada menos que los componentes del relato picaresco ${ }^{8}$.

Asimismo, el razonamiento entre Sancho y don Quijote a propósito del caballero andante ideal, desarrollado en el capítulo XXI, se manifiesta como una verdadera premisa de crítica literaria de cara a la oposición con la novela picaresca, más o menos anclada en la historia circundante y con un poética comprometida ${ }^{9}$, frente a las posibilidades narrativas de signo idealista, o romances. Un contrapunto que se erige en eje semántico de la aventura de los galeotes. Más concretamente, cuando don Quijote elucubra sobre las prendas del buen caballero andante, se refiere a ese eventual sabio que habrá de transcribir su historia según el modelo de la caballeresca: "Bien es verdad que yo soy hijodalgo de solar conocido, de posesión y propriedad y de devengar quinientos sueldos, y podría ser que el sabio que escribiese mi historia deslindase de tal manera mi parentela y decendencia, que me hallase quinto o sesto nieto de rey" (232). Una posibilidad, pero por negativa, que también ha tenido en cuenta Sancho un momento antes (“... no faltará quien ponga en escrito las hazañas de vuestra merced, para perpetua memoria", 229) y que vislumbró el propio don Quijote nada más empezar la obra, en una especie de conjuro anticipador: "¡Oh tú sabio encantador, quienquiera que seas, a quien ha de tocar ser el coronista de esta peregrina historia!"' (47).

Todas estas referencias, así como la mención a Cide Hamete antes comentada, reiteran la posibilidad narrativa en tercera persona por parte de un cronista fidedigno que refiere los acontecimientos de un modo verosímil. En el episodio de los galeotes, sin embargo, Cervantes trae a la palestra un principio narrativo distinto, que se ha puesto definitivamente de moda unos años antes con el Guzmán de Alfarache (1599-1604), y que consiste en que el protagonista cuente su vida de forma autobiográfica. Todos estos juegos narrativos y otros que se constatarán ahora, llevan a considerar que esta segunda alternativa de contar no le parece del todo adecuada o verosímil. En efecto, la aparición de "hasta doce hombres a pie, ensartados como cuentas en una gran cadena de hierro por los cuellos, y todos con esposas a las manos" (235) da lugar a que don Quijote pueda aplicar el mecanismo de la caballería andante. No obstante, antes de ponerse manos a la obra y ejecutar su oficio liberador -toda vez que se percata de que esa gente va privada de libertad-, pretende informarse de la causa por la que han sido forzados. De modo muy cortés, eso sí, sin los tan acostumbrados desafueros de antaño, pregunta a tal propósito a uno de los cuadrilleros. Pero éste le responde con cajas destempladas que son "galeotes, gente de Su Majestad, que iba a galeras, y que no había más que decir, ni él tenía más que saber" (236). Sin cejar en su empeño, antes lo contrario, don Quijote insiste en saber detalladamente y en particular los avatares que han conducido a los prisioneros a su estado actual $\mathrm{y}$, entonces, uno de los guardas de a caballo le sugiere que "se lo pregunte a ellos mesmos, que ellos lo dirán si quisieren, que sí querrán, porque es gente que recibe gusto de hacer y decir bellaquerías" (237). De esta forma, así pues, lo lleva a cabo don Quijote; pero sólo hay espacio para que

\footnotetext{
${ }^{8}$ La poética picaresca ha sido definida, entre otros, por F. Lázaro Carreter, Lazarillo de Tormes en la picaresca, Barcelona, Ariel, 1983 ( $2^{\mathrm{a}}$ ed. aumentada) y F. Rico, La novela picaresca y el punto de vista, Barcelona, Seix Barral, 2000 ( $6^{a}$ ed. corregida y aumentada.) Además véase n. 42.

${ }^{9}$ Ver A. Rey Hazas, Deslindes de la novela picaresca, Málaga, Universidad, 2003.
} 
interrogue a seis de los doce ${ }^{10}$, porque antes de acabar se arma una tremenda trifulca, cuando decide redimir a los presos (244-248).

Por orden riguroso en la narración, el primer galeote le contesta al caballero refiriéndole sus desventuras; sin embargo, el segundo se queda callado y es este primero quien le sirve de portavoz. Ahora bien, don Quijote entiende muy poco de lo que le farfulla el apresado, porque éste hace uso de la jerigonza, o sea, del lenguaje cifrado de la germanía. Y así se lo hace saber otra de las guardas que actúa ahora de intérprete. Quiere esto decir que la intelección de las circunstancias de los galeotes funciona únicamente en el nivel de lo visual, siendo por tanto tan sólo aparente. Porque en cuanto a la decodificación de su verdadero sentido se muestra críptica, al no poseer don Quijote las claves del código germanesco ${ }^{11}$. Precisamente, en Rinconete y Cortadillo, cuya primera versión parece anterior al Quijote, puesto que se cita en I, XLVII (542), ocurre una situación muy similar, cuando un muchacho ya iniciado instruye a los protopícaros en el código hampesco. Les dice para ello: "Y, porque sé que me han de preguntar algunos vocablos de los que he dicho, quiero curarme en salud y decírselo antes que me lo pregunten" $(180)^{12}$.

El procedimiento con los galeotes tercero y cuarto resulta bastante paralelo al de la pareja anterior, porque el segundo de ellos no habla y es el quinto quien cuenta a don Quijote las penalidades de su vida. Sorpresivamente, el caballero hace un elogio del oficio de tercero ${ }^{13}$, que habría que encuadrar en la tradición retórica de los encomios paradójicos, aunque no necesariamente relacionarlo con la Moria erasmiana ${ }^{14}$. Con el sexto condenado, exactamente en mitad de la cadena de presos, llega don Quijote al más sobresaliente de los delincuentes, el famoso Ginés de Pasamonte ${ }^{15}$, personaje clave para comprender la opinión de Cervantes en torno a la novela picaresca y su poética. Cervantes lo presenta de esta guisa:

Tras todos estos venía un hombre de muy buen parecer, de edad de treinta años, sino que al mirar metía el un ojo en el otro un poco. Venía diferentemente atado que los demás, porque traía una cadena al pie, tan grande, que se la liaba por todo el cuerpo, y dos argollas a la garganta, la una en la cadena y la otra de las que llaman guardaamigo o pie de amigo, de la cual decendían dos hierros que llegaban a la cintura, en los cuales se asían dos esposas, donde

\footnotetext{
10 Téngase en cuenta K. L. Selig, "Don Quixote I/22: The Exploration of Form in Mini-Form", en The Two Hesperias: Literary Studies in Honor of Joseph G. Fucilla on the Occasion of His 80th Birthday, Madrid, Porrúa, 1977, pp. 349-57.

${ }^{11}$ Cfr. M. García Posada, "El episodio quijotesco de los galeotes: Ambigüedad lingüística y significación", Hispanic Review, XLIX (1981), pp. 197-208.

${ }^{12}$ Todas las citas de las Novelas ejemplares van por la ed. de J. García López (Barcelona, Crítica, 2001).

13 “...El oficio de alcahuete, que es oficio de discretos y necesarísimo en la república bien ordenada, y que no le debía ejercer sino gente muy bien nacida..." (239).

${ }^{14}$ Cfr. F. Sánchez Escribano, "Un tema erasmiano en El Quijote, I, XXII", Revista Hispánica Moderna, XIX (1953), pp. 88-93. Además: O. Green: "Don Quijote and the Alcahuete", en Estudios dedicados a James Homer Herriott, Madison, Univ. of Wisconsin, 1966, pp. 109-116 y A. Redondo, "De las terceras al alcahuete del episodio de los galeotes en el Quijote (I, 22). Algunos rasgos de la parodia cervantina", en Otra manera de leer "El Quijote". Historia, tradiciones culturales y literarias, Madrid, Castalia, 1997, pp. 347-362.

${ }^{15}$ No me ocupo aquí de la conocida tesis de M. de Riquer, Cervantes, Pasamonte y Avellaneda, Barcelona, Sirmio, 1988, que ha diseñado un modelo vivo para el galeote. Véase además E. C. Riley, ¿Cómo era Pasamonte?”, en Actas del Tercer Congreso Internacional de la Asociación de Cervantistas, ed. A. Bernat Vistarini, Palma, Universitat de les Illes Balears, 1998, pp. 85-96. Y ahora: H. Percas de Ponseti, "Pasamonte fue Avellaneda", Cervantes, 22, 1 (2002), pp. 127-154.
} 
llevaba las manos, cerradas con un grueso candado, de manera que ni con las manos podía llegar a la boca ni podía bajar la cabeza a llegar a las manos (241).

La razón para tantas prevenciones proviene de su grado de peligrosidad, muy superior al de sus compañeros. De hecho, esta es la segunda vez que va a galeras, porque ya estuvo por diez años en una ocasión anterior. Lleno de arrogancia, Pasamonte se presenta ante don Quijote como un hombre de letras, como un pícaro escritor de su propia vida. Dice exactamente, "sepa que yo soy Ginés de Pasamonte, cuya vida está escrita por estos pulgares" (242), hecho que confirma el comisario de la expedición: "Dice verdad [...], que él mesmo ha escrito su historia, que no hay más que desear, y deja empeñado el libro en la cárcel en docientos reales" (242). Don Quijote, por su parte, se extraña ante una prenda literaria de tanto valor y le pide cuentas de su bondad al galeote, quien con la misma arrogancia de siempre, le espeta una bravata de la siguiente magnitud: "Es tan bueno respondió Ginés-, que mal año para Lazarillo de Tormes y para todos cuantos de aquel género se han escrito o escribieren. Lo que le sé decir a voacé es que trata verdades y que son verdades tan lindas y tan donosas que no pueden haber mentiras que se le igualen" (243).

Desde luego, las tales palabras han suscitado múltiples comentarios de diverso criterio sobre la conceptuación del género picaresco a la altura de 1605 o, más en concreto, acerca de la opinión que éste le merece a Cervantes, su primer y más lúcido crítico ${ }^{16}$. Lo que sí resulta claro es que Pasamonte, quien por galeote que cuenta su vida, y quizás por otras razones menos evidentes ${ }^{17}$, recuerda indefectiblemente a Guzmán de Alfarache, no llega a nombrarlo, sino que alude al iniciador de la serie literaria, al Lazarillo de Tormes. Ahora bien, aunque esa omisión no deja de ser significativa, a guisa de ninguneo, la mención colectiva a las obras del mismo signo o especie, escritas ya o todavía por escribir, alude, por supuesto, a un ramillete de obras que en 1605 podría estar conformado, además del segundo Lazarillo (1555), por el Guitón Onofre, el Buscón, ambos de circulación manuscrita y acabados en 1604; la Pícara Justina, también como los dos anteriores en clara confrontación con el Guzmán ${ }^{18}$; y, por supuesto, su continuación apócrifa (1602) y la segunda parte de 1604. En definitiva, entre 1599 y 1605 , como ha estudiado Riley ${ }^{19}$, se produce una etapa crítica y renovadora en la prosa de ficción, que tiene mucho que ver con esa reacción frente al Guzmán. Y en el centro de toda esa polémica se sitúa el capítulo de los galeotes.

\footnotetext{
${ }^{16}$ El origen de casi todos lo ha sido el de C. Guillén, "Luis Sánchez, Ginés de Pasamonte y el descubrimiento del género picaresco $(1965,1968)$ ”, en El primer Siglo de Oro. Estudios sobre géneros y modelos, Barcelona, Crítica, 1988, pp. 197-211.

${ }^{17}$ Por ejemplo, P. N. Dunn (“Cervantes De/Re-Constructs the Picaresque”, Cervantes, 2.2 [1982], pp. 109-131, p. 119) se fija en la recurrencia 2 sílabas $+d e+4$ sílabas entre los nombres de Ginés de Pasamonte y Guzmán de Alfarache. Por otro lado, A. Redondo, "De Ginés de Pasamonte a maese Pedro", en Otra manera de leer "El Quijote”..., pp. 251-264, 255, n.15, subraya la alusión "Basta, que podría ser que saliesen algún día en la colada las manchas que se hicieron en la venta", dependiente tal vez de Guzmán, VI.

${ }^{18}$ Váyase a J. M. Micó, "Prosas y prisas en 1604: El Quijote, el Guzmán y la Pícara Justina" en Hommage à Robert Jammes, ed. F. Cerdan, Toulouse, Presses Universitaires du Mirail. 1995. Vol. III, pp. 827-848.

${ }^{19}$ En varios lugares, pero más al caso en "Una cuestión de género" y "La novela de caballerías, la picaresca y la primera parte del Quijote" en La rara invención. Estudios sobre Cervantes y su posteridad literaria, Barcelona, Crítica, 2001, pp. 185-215. Además, "Tradición e innovación en la novelística cervantina", Cervantes, 17, 1 (1997), pp. 46-61.
} 
Claudio Guillén desarrolló de modo magistral la idea del concepto de género picaresco a partir de la interacción del Lazarillo y el Guzmán, cuando llega a identificarse que en el segundo se reproducen los esquemas literarios iniciados por el primero ${ }^{20}$. Tan es así que tras unos años de escasa proliferación editorial (antes de 1599 sólo existen seis impresiones del librito), nueve semanas después de la aparición de la obra de Alemán se reedita el precursor, registrándose entre 1599 y 1605 diez ediciones ${ }^{21}$. Pues bien, las palabras de Pasamonte vendrían a confirmar, de modo más o menos explícito, lo que se puede derivar de la producción editorial, que en torno a 1604 se ha conformado un género literario de prolija descendencia. Por eso en el prólogo del Diálogo intitulado el Capón, anterior quizá al Guzmán de Alfarache ${ }^{22}$, sólo se habla de la novela anónima. Al contar su vida, Velasquillo establece un reto con la obra bastante en paralelo con el de Pasamonte, al manifestar: “... serví después a un cura capón que sin duda debió de ser pupilo del clérigo de Maqueda a quien sirvió Lazarillo de Tormes, y con todos estos [amos] me pasaron cosas que pudiera hacer otro libro mejor que el suyo" (84-85) ${ }^{23}$. Sin embargo, ya a la altura de 1621 el concepto de lo picaresco engloba también al Guzmán y el género resultante de su correspondencia con el Lazarillo. Así, en El necio bien afortunado de Salas Barbadillo, Ceñudo, que está haciendo relación del discurso de su vida, comenta: "Sentía yo en mí cierta codicia de libros, que no me dejaba. Salíame al campo con algunos de los que tenía mi tío, El Pícaro, y Laçarillo y otros deste género" 24 . Desde luego, son dos textos que flanquean al del Quijote y que lo ponen en perspectiva más precisa.

A más de esto, importa en este caso la opinión que le merece a Cervantes la fórmula picaresca y, siendo más exactos, el representante axiomático del género, la obra de Mateo Alemán. En La ilustre fregona, por ejemplo, sí se refiere al Pícaro por antonomasia, al emparentarlo con Carriazo, personaje de indudable inclinación picaresca ${ }^{25}$, de quien afirma que "él salió tan bien con el asumpto de pícaro, que pudiera leer cátedra en la facultad al famoso de Alfarache" (371). Parece bastante claro, en este sentido, que el Quijote, y las otras obras de Cervantes en los aledaños de la picaresca, que en orden cronológico (16041612) serían Rinconete y Cortadillo ${ }^{26}$, La ilustre fregona y El Coloquio de los perros ${ }^{27}$,

\footnotetext{
${ }^{20}$ Art. cit.

${ }^{21}$ Además de las nueve citadas por Guillén, el llorado Jesús Sepúlveda nos ha redescubierto otra más en el mismo año que el Quijote: "Noticia de una edición olvidada del Lazarillo (Alcalá de Henares, viuda de Juan Gracián, 1605)", Quaderni di Letterature iberiche e iberoamericane, 26 (1996-1997), pp. 5-16.

${ }^{22}$ Precisamente por esta cuestión: H. Mancing, "El Diálogo del capón y la tradición picaresca", en Actas del VI Congreso de la Asociación Internacional de Hispanistas, Toronto, Universidad, 1980, 494-497.

${ }^{23}$ Diálogo intitulado el Capón, ed. V. Infantes y M. Rubio, Madrid, Visor, 1993.

${ }^{24}$ Ed. de la Sociedad de Bibliófilos Españoles, 1894, p. 205.

25 "En fin, en Carriazo vio el mundo un pícaro virtuoso, limpio, bien criado y más que medianamente discreto. Pasó por todos los grados de pícaro hasta que se graduó de maestro en las almadrabas de Zahara, donde es el finibusterrae de la picaresca", 374.

${ }^{26}$ Resulta fundamental: J. García López, "Rinconete y Cortadillo y la novela picaresca”, Cervantes, 19.2 (1999), pp. 113-124.

27 Véanse, por ejemplo: G. Soberano, "El Coloquio de los perros en la picaresca y otros apuntes", Hispanic Review, 43,1 (1975), pp. 25-41; V. Díaz Balsera, "Un diálogo cervantino con la picaresca: intertextualidad, desplazamiento y apropiación en el Coloquio de los perros", Crítica Hispánica, XVII (1995), 2, pp. 185-202; D. Mañero Lozano, "Diálogo y picaresca en el Coloquio de los perros", Bulletin Hispanique, 2 (2004), pp. 497-520.
} 
significan una alternativa, aunque diferenciadas en su respuesta ${ }^{28}$, al modelo guzmanezco. De suerte que para muchos no habría existido la obra sin mediar el pícaro de Alfarache ${ }^{29}$. Cervantes no está de acuerdo con los principios rectores del Guzmán, lo que no quiere decir que no valore el libro en lo que vale, puesto que parece influirle desde Rinconete y Cortadillo $^{30}$. Ahora bien, de esto no se ha de colegir que Cervantes mida con el mismo rasero a todas las obras de la serie. No se puede entender la cuestión de Cervantes y la picaresca a partir de una simple disyuntiva de aceptación o rechazo ${ }^{31}$. Lo ha explicado muy bien Márquez Villanueva al sostener que "Su actitud ante la picaresca es compleja, con acercamientos y retrocesos que, a lo largo de sus mejores años, dibujan casi una coquetería hacia la misma" ${ }^{\text {32 }}$. Además, Riley ha ido perfilando la idea de que Cervantes se opone el Guzmán pero puenteándolo, es decir, yendo directamente a los inicios del género, a los precedentes antiguos y sus descendientes renacentistas ${ }^{33}$. En una palabra, al Lazarillo de Tormes, piedra de toque para la conformación genérica de la picaresca, en una primera etapa de experimentación en la prosa de ficción, entre 1550 y 1560. Esto que para Riley resulta evidente en el Coloquio de los perros, también ocurriría, y de diversas maneras, en este punto de los galeotes.

Como era de esperar, en cuanto a los retrocesos o rechazos, el primer elemento que preocupa a Cervantes es el asunto de la verosimilitud de la obra picaresca. Pasamonte sostiene, al respecto, que su libro es absolutamente verosímil ("trata verdades") y opone este rasgo al resto de la serie a la que acaba de aludir ("que son verdades tan lindas y tan donosas que no pueden haber mentiras que se le igualen"), obras a las que tacha de mentirosas o fraudulentas. Esta dolencia de inverosimilitud provendría, según Cervantes, de la instancia narrativa en primera persona, dado que el narrador de su propia vida supone en el caso de los pícaros una voz sin ningún crédito, con propósitos espurios, falaz en su objetivo y conformada mediante los usos de la jerigonza. La actuación de los galeotes y del mismo Lázaro, sin ir más lejos, demuestra esta base de mendacidad. Curiosamente, en la obra que cierra el periplo picaresco (1646), Estebadillo González parece remedar las intenciones de Pasamonte culpando a los modelos de inverosimilitud, para salir airoso en su historicidad: “...Yo me llamo Estebanillo González, flor de la jacarandina. Y te advierto que no es [mi vida] la fingida de Guzmán de Alfarache, ni la fabulosa de Lazarillo de Tormes, ni la supuesta del caballero de la Tenaza, sino una relación verdadera con parte presente y testigos de vida y contestes, que los nombro a todos para averiguación y prueba

\footnotetext{
${ }^{28}$ Cfr. García, art. cit., p. 114.

${ }^{29}$ Desde Américo Castro.

${ }^{30} \mathrm{~S}$. Zimic ha establecido muchos paralelos en Las Novelas ejemplares de Cervantes, Madrid, Siglo XXI, pp. 82141.

${ }^{31}$ Al margen de otros estudios citados y por citar, tratan sobre Cervantes y la picaresca: G. A. Alfaro, "Cervantes y la novela picaresca", Anales Cervantinos, X (1971), pp. 23-31; M. Bataillon, "Relaciones literarias", en Suma cervantina, ed. J. B. Avalle-Arce, Londres, Támesis, 1973, pp. 215-232; H. H. Reed, "Theatricality in the Picaresque of Cervantes", Cervantes, 7, 2 (1987), pp. 71-84; M. Durán, "Picaresque Elements in Cervantes's Works", en The Picaresque: Tradition and Displacement, ed. G. Maiorino, Minneapolis, University of Minnesota Press, 1996.

${ }^{32}$ F. Márquez Villanueva, "La interacción Alemán-Cervantes", en Trabajos y días cervantinos, Alcalá de Henares, Centro de Estudios Cervantinos, 1995, pp. 241-297. La cita, de la p. 251.

${ }^{33}$ E. Riley, "Los antecedentes del Coloquio de los perros", en La rara invención..., pp. 239-254.
} 
de mis sucesos..." (13-14) $)^{34}$. Pero la falla de la novela picaresca en cuanto a su exposición autobiográfica no acaba aquí para Cervantes. El género autobiográfico ${ }^{35}$ adolece de una precariedad básica con respecto a la tercera persona omnisciente. Y es que una vida propia no puede narrarse en su integridad hasta el momento preciso de la muerte. Se produce, así pues, lo que Riley ha denominado el "callejón sin salida de la autobiografía", por la imposibilidad de cerrar definitivamente la historia, pero, a la vez, la necesidad acuciante de acabarla de una forma $\mathrm{u}$ otra $^{36}$. Añado yo ahora que el remate espurio de la edición alcalaína del Lazarillo parece dar respuesta a esta paradoja. El libro, que como carta que es, se cierra definitivamente con la data, deja paso, sin embargo, a la eventualidad de nuevas aventuras en próximas misivas: "De lo que de aquí adelante me suscediere, avisaré a Vuestra Merced"37. Un prolongar la vida del pícaro que obtendrá un eco inmediato con la continuación anónima de $1555^{38}$ y que se expandirá incluso con la de Juan de Luna en 1620. La paradoja, por tanto, atañe a la antinomia entre vida, o materia narrativa, y libro, u obra literaria. Pasamonte, en efecto, ha escrito un libro, y por eso tanto él como el cuadrillero lo refieren con formas perfectivas ("yo soy Ginés de Pasamonte, cuya vida está escrita"; "él mesmo ha escrito su historia"). Asimismo, don Quijote, quizá con extrañeza ante tal aseveración, pregunta por la resolución del mismo, “¿Y está acabado?”, dice. Pero la respuesta de Pasamonte a este tenor parece altamente ambigua, al afirmar que el libro no puede estar rematado sin haberlo hecho su vida. Y precisa, "Lo que está escrito es desde mi nacimiento hasta el punto que esta última vez me han echado en galeras", concluyendo, "...allí tendré lugar de acabar mi libro" (243), a lo que añade un comentario ("y en las galeras de España hay más sosiego de aquel que sería menester") que bien podría provenir de la alusión de Alemán sobre el "tiempo ocioso de la galera", sita en la Declaración. Ginés, así pues, parece haber escrito una primera parte de su proyecto que, en buena lógica con el canon picaresco, se extiende desde los orígenes hasta el presente del acto narrativo. Y, en paralelo a las circunstancias del Guzmán, ese cierre ha de tener lugar en las galeras, a las que va por otros cuatro años. Con esta idea de rematar la empresa literaria, parece proyectar una segunda parte de la obra. Según esto, Cervantes estaría mofándose de la apertura semántica de las obras picarescas, y así desde el Lazarillo, que permite la continuación en partes posteriores. En efecto, la primera parte del Guzmán hay que entenderla desde el remate de la segunda, cuando el galeote arrepentido cuenta su vida. El proyecto de libro, así pues, está perfectamente planificado. En la Declaración para el entendimiento de este libro Mateo Alemán afirma que "Él mismo escribe su vida desde las galeras, donde queda forzado al remo por delitos que cometió, habiendo sido ladrón famosísimo, como largamente lo verás en la segunda parte"39. La unidad del libro es susceptible de bipartirse o tripartirse, incluso, como ocurre con el Guzmán, cuya última

\footnotetext{
${ }^{34}$ La vida y hechos de Estebadillo González, ed. A. Carreira y J. A. Cid, Madrid, Cátedra, 1990.

${ }^{35}$ Guillén, art. cit., p. 209.

${ }^{36}$ Resulta fundamental el artículo de Riley, "Sepa que yo soy Ginés de Pasamonte" en La rara invención..., pp. 51-72 (p. 61) y las apostillas de M. Moner, "La vida no acabada de Ginés de Pasamonte", Bulletin of Spanish Studies, LXXXI, 4-5 (2004), pp. 523-528.

${ }^{37}$ Lazarillo de Tormes, ed. de Francisco Rico, Madrid, Cátedra, 1987.

38 Véase V. Núñez Rivera, "Claves para el segundo Lazarillo, 1555. El continuador anónimo interpreta su modelo", Bulletin Hispanique (2003), 2, pp. 333-369.

${ }^{39}$ Mateo Alemán, Guzmán de Alfarache, ed. Florencio Sevilla, Madrid, Ollero, 2003, p. 69.
} 
sección se ofrece como promesa de una tercera parte. Algo parecido debe de tener en su mente Ginés de Pasamonte al postergar el cierre de la obra.

No obstante, Cervantes, con su suprema inteligencia, invalida el proyecto de consecución de la historia del galeote, toda vez que don Quijote lo libera del castigo. Desde el momento en que goza de libertad se imposibilita la estancia en galeras ${ }^{40}$. Y esto lo sabemos bien en tanto en cuanto Ginés de Pasamonte vuelve a aparecer en el Quijote de 1615, deambulando libre de aquí para allá. Todo lo relativo al robo del rucio en hábito de gitano no nos interesa al presente, o, al menos, sólo muy tangencialmente, por lo que no entraré a comentarlo en profundidad. Únicamente mencionaré el hecho de que se le hace autor del robo en la edición revisada de 1605, a través de sendos añadidos en I, XXIII y I, $\mathrm{XXX}^{41}$, plagados de problemas, incertidumbres que serán comentadas en II, IV. Aparte de estas intermitencias con el robo del rucio, Pasamonte, y esto sí es del máximo interés, porque no había ninguna necesidad narrativa para ello, reaparece disfrazado de Maese Pedro en II, XXVII. Ha cambiado, por tanto, en relación con los designios primeros, porque ya no es galeote, por culpa de don Quijote, sino titiritero fraudulento. Con la reactivación del bandido, Cervantes, muy aposta y no por casualidad, pretende parodiar dos de los extremos fundamentales del relato picaresco. Por un lado, la premisa tiránica del determinismo autobiográfico. No se olvide que la presuposición del galeote se transforma gracias a la casualidad, a la Fortuna cambiante. Pero además, se contraviene el principio de la narración autobiográfica de la que se hablaba en I, XXII. Ahora es Cide Hamete - y qué curioso que se le nombre ab initio, como en ese capítulo-, quien aclara todos los avatares de Pasamonte, desde su liberación hasta el momento actual. La segunda parte de su historia se ha transformado irremediablemente. Como don Quijote, teme por su futuro y, también como él, se traslada hacia Aragón, huyendo de la Santa Hermandad, dos circunstancias que lo contraponen al héroe en marcada polaridad:

Entra Cide Hamete, coronista desta grande historia [...] Dice, pues, que bien se acordará el que hubiere leído la primera parte desta historia de aquel Ginés de Pasamonte a quien entre otros galeotes dio libertad don Quijote en Sierra Morena [...] Este Ginés, pues, temeroso de no ser hallado de la justicia, que le buscaba para castigarle de sus infinitas bellaquerías y delitos, que fueron tantos y tales, que él mismo compuso un gran volumen contándolos, determinó pasarse al reino de Aragón y cubrirse el ojo izquierdo, acomodándose al oficio de titerero, que esto y el jugar de manos lo sabía hacer por estremo (855-856).

De pasada, Cervantes acaso se burle además de una característica del Guzmán que, asimismo, se ridiculiza por entre los consejos metaliterarios que Cipión le brinda a Berganza al contarle los sucesos de su vida. El perro crítico le previene de la prolijidad a base de digresiones, las cuales metaforiza con la imagen de las colas de pulpo: "Quiero decir que la sigas de golpe, sin que la hagas que parezca pulpo, según la vas añadiendo colas" (568). En efecto, Benengeli escribe que Pasamonte "compuso un gran volumen" y él mismo había dicho en I, XXII, que en las galeras tendría ocasión de "acabar mi libro que me quedan muchas cosas que decir". El tal libro era, desde luego, tan grueso y verboso como el de Guzmán. Más importante que esta burla, en cierto modo marginal, resulta sin

\footnotetext{
${ }^{40}$ Martí, el continuador apócrifo, promete una tercera parte donde contará cómo se escapó de galeras. No sé si esto pudo influir en Cervantes.

${ }^{41}$ Ed. cit., Apéndice, pp. 1233-34.
} 
duda la invalidación a la que somete Cervantes el "caso" de la novela de Pasamonte. Se ha dado en llamar así al cierre estructural que explica y da coherencia al desarrollo novelesco anterior, como ocurre con el menage à trois lazarillesco o el arrepentimiento de Guzmán ${ }^{42}$. No embargante, el relato de Pasamonte no parece obedecer a un principio estructurante de ese calado, tal como se manifiesta en el Quijote de 1605. Tan sólo se presenta como una sucesión abierta o informe de acontecimientos, como lo son, por ejemplo, las biografías contemporáneas de los soldados, entre ellos los cautivos ${ }^{43}$. Por eso puede dilatarse ad infinitum, hasta el desenlace de la vida, porque no existe un caso vertebrador. Ahora bien, si fuese certera la suposición de Riley ${ }^{44}$, con la actitud nueva de Maese Pedro hacia don Quijote -que entre sollozos lo alaba de ser amparo de los menesterosos, por más que, en realidad, pretenda aprovecharse de su liberalidad al resarcirse de la escabechina que ha hecho con las figuras del retablo (I, XXVI)-, tal vez existiera un amago de arrepentimiento, lo cual abriría insospechadas relaciones de sentido con el de Alfarache.

Si las cuestiones narrativas y estructurales de la novela picaresca resultan fundamentales en la caracterización cervantina de la misma, no lo es menos la razón de ser por antonomasia para todas las ulteriores marcas canónicas. El determinismo vital que diseña la vida del pícaro también configura su expresión literaria en primera persona. Frente a ese dogmatismo, Cervantes se decanta por la libertad más absoluta en cuanto a la vida y, sobre todo, en cuanto a la literatura, en un ejercicio que Rey Hazas ha denominado como "poética de la libertad"45. Y es que la libertad radical del hombre se opone a la tiranía de la herencia indigna que estigmatiza al pícaro. Los hombres son hijos de sus obras y la Fortuna cambiante se encarga de elevarlos sobre las circunstancias o de abatirlos definitivamente. Don Quijote en I, XXI afirma que "unos fueron, que ya no son, y otros son, que ya no fueron" (233). Y también se hace eco del mismo argumento el reflexivo Cipión: “... los que ayer estaban en la cumbre de la rueda de la fortuna, hoy están hollados y abatidos a los pies de la desgracia [...] Digo, pues, que el verdadero sentido es un juego de bolos, donde con presta diligencia derriban los que están en pie y vuelven a alzar los caídos" (605). La prueba más evidente de esta propuesta de libertad radica en el pícaro por vocación que representa Carriazo. Y también podrían serlo Rincón y Cortado, de orígenes humildes pero no abocados a la delincuencia por linaje. Pero de modo mucho más sutil se aprecian otras referencias solapadas en el episodio de los galeotes. Por ejemplo, con la misma liberación de los delincuentes y, como hemos visto, del propio Pasamonte, don Quijote lo exime del castigo en galeras y subvierte el determinismo de su libro en ciernes. A esa necesidad acaso aluda la mención de Pasamonte de que lo que tiene que escribir se lo sabe de coro ${ }^{46}$, de memoria y sólo desde su propio punto de vista, inamovible y sesgado. Cipión, en el mismo sentido, se enfrenta a la "maldita plaga de la murmuración", ejercicio predilecto de los

\footnotetext{
${ }^{42}$ Lo ha desarrollado F. Cabo Aseguinolaza, El concepto de género y la literatura picaresca, Santiago de Compostela, Universidad, 1992.

${ }^{43}$ García, art. cit., p. 119.

44 “Sepa que yo...", pp. 69-70.

${ }^{45}$ Entre otros lugares, véase, A. Rey Hazas, "El Guzmán de Alfarache y las innovaciones de Cervantes" en Atalayas del Guzmán de Alfarache, ed. Pedro M. Piñero, Sevilla, Universidad, 1999, pp. 177-217.

${ }^{46}$ Compárese con lo que dice Campuzano: “...Todo lo tomé de coro; y, casi por las mismas palabras que había oído, lo escribí otro día, sin buscar colores retóricas para adornarlo, ni qué añadir ni quitar para hacerle gustoso" (537).
} 
pícaros y de Guzmán en particular. Además de todo esto, también esa imagen de la cadena a la que van atados los presos habladores significaría un símbolo de actuación en contra de la voluntad ("van de por fuerza y no de su voluntad"). Frente a esa cadena de las predestinaciones se alza el principio absoluto del libre albedrío, "que es libre nuestro albedrío [...] siendo, como digo, cosa imposible forzar la voluntad" (240), como mantiene don Quijote cuando alaba al alcahuete.

Con la recusación del determinismo vital se llega de nuevo a la cuestión de la perspectiva autobiográfica, a la tiranía del punto de vista único del emisor. Cervantes quizá sea el primero en poner de manifiesto la trascendencia del receptor en la decodificación de la intencionalidad picaresca. Téngase en cuenta que los galeotes cuentan porque don Quijote pregunta por sus vidas. Y de ello se percata Ginés de Pasamonte, que lo tacha de proceder abusivamente: "que ya enfada con tanto querer saber vidas ajenas" aboga por la presencia de dos puntos de vista como mínimo, tal como sucede en el Quijote con la incorporación de Sancho ${ }^{48}$. La perspectiva monolítica del pícaro que conforma toda la novela le parece insuficiente. Por tanto, la intervención del receptor en el mensaje picaresco, de cuya pregunta, por querer saber vidas ajenas, ha surgido el relato, se confirma como un generador de sentido. Esto resulta bien patente en el Lazarillo, dado que la carta del pregonero se trata de una contestación, la mitad, pues, de un diálogo, a una misiva previa de interrogación. Puede que Cervantes rechace la novela picaresca en un sentido estricto, pero, desde luego, coquetea con ella y se queda con lo que entiende como más productivo. Cervantes no escribió nunca una novela picaresca, entre otras cosas porque no quiso; lo que hizo fue integrar discursos picarescos en estructuras novelescas de envergadura superior, e incluso teatrales, así el caso en Pedro de Urdemalas (vv. 600-767). $\mathrm{Y}$ es que junto a la novela picaresca existe desde los orígenes la posibilidad del discurso picaresco sin más. Un acto enunciativo que, por supuesto, cuando coincide por entero con la estructura narrativa conforma una novela. Así ocurre en el Lazarillo, en donde el discurso de Lázaro se superpone a la estructura epistolar. Quiere esto decir que la vida que relata Pasamonte da lugar a un discurso picaresco en ciernes, un discurso que, como la vida de Lázaro, surge por la pregunta de don Quijote. Rincón y Cortado, tanto como Berganza y Cipión, se cuentan, o habrán de contarse (545), mutuamente sus vidas. En ambos casos, resulta fundamental la perspectiva del receptor, quien escucha y a su vez cuenta. No nos encontramos ante novelas picarescas, porque existe un narrador en tercera persona que da cauce a los parlamentos de los personajes, pero sí existe el discurso picaresco, una categoría que debería tenerse en cuenta a la hora de explicar el concepto de lo picaresco, en la amplia gama que oscila entre el estatuto funcional de novela picaresca y la mera naturaleza semántica del gusto picaresco ${ }^{49}$. Y la cosa es que ese tipo de discurso se observa desde

\footnotetext{
${ }^{47}$ Sobre el tema ha tratado J. H. Silverman, "Saber vidas ajenas: Un tema de vida y literatura y sus variantes cervantinas", Papeles de Son Armadans, 89 (1978), pp. 197-212.

${ }^{48}$ En este sentido, habló de un realismo dogmático (el de la picaresca) y un realismo objetivo (el de Cervantes) C. Blanco Aguinaga en un artículo fundacional: "Cervantes y la picaresca. Notas sobre dos tipos de realismo", $N R F H$, XI (1957), pp. 313-342. Con todo, relativiza la naturaleza del diálogo cervantino (puro y perspectivista) y el monólogo alemaniano (pluriforme, abierto, dialogal) G. Soberano, "De Alemán a Cervantes: monólogo y diálogo", en Homenaje al Profesor Muñoz Cortés, Murcia, Universidad, 1977, pp. 713-729.

${ }^{49}$ Por citar la dicotomía propuesta por A. Del Monte, Itinerario de la novela picaresca española, Barcelona, Lumen, 1971.
} 
siempre. Por ejemplo, se da en el Baldo (1542) con el relato de las vidas de Cingar y Falcheto; o en el Diálogo intitulado el Capón (de entre 1597 y 1600), con el prólogo de Vañuelos o la narración de Velasquillo. Asimismo, en la Segunda parte del Guzmán apócrifa se inserta el relato de Francisco de León (I, 1) y en el Guzmán de 1604 acontece la intervención del propio Sayavedra.

Por lo dicho, parece que Cervantes está más cercano a las propuestas del Lazarillo que del Guzmán de Alfarache. Siquiera por la presencia ambigua de ese Vuestra Merced que dota de sentido a la obra y le confiere un marco estructural englobador al discurso del pregonero. Si esta estimación fuera cierta casaría perfectamente con algunos guiños a modo de homenaje intencionado que Cervantes va desperdigando en torno a la actuación de Pasamonte. Precisamente, el delincuente es conocido por un sobrenombre que detesta de forma radical y que recuerda sin remedio al de Tormes: "que por otro nombre llaman Ginesillo de Parapilla" ${ }^{\circ 0}$. Asimismo, el título de la obra (La vida de Ginés de Pasamonte) está calcado sobre La vida de Lazarillo de Tormes. Y tal vez en el juramento que hace Pasamonte para que no lo apoden más con el antedicho nombre ("mas yo haré que no me lo llamen, o me las pelaría donde yo digo entre mis dientes", 242) rememore la blasfemia de Lázaro cornudo cuando pretende defenderse de los murmuradores a toda costa ${ }^{51}$. Incluso la premisa para la enunciación picaresca de "querer saber vidas ajenas" podría explicarse a partir de los lamentos del escudero en el tercer tratado: "Por Dios, si con él [un caballero de alta talla] topase, muy gran su privado pienso que fuese, y que mil servicios le hiciese, porque yo sabría [...] decirle bien de lo que bien le estuviese, por el contrario, ser malicioso mofador; malsinar a los de casa y a los de fuera; pesquisar y procurar de saber vidas ajenas para contárselas, y otras muchas galas de esta calidad, que hoy día se usan en palacio y a los señores de él parecen bien" (104-105). Repárese, por otro lado, en que aquí es Lázaro de Tormes quien se convierte en receptor de la vida del escudero, intercambiando su papel inicial. Por último, acaso el empleo de la paradoja burlesca por parte de don Quijote a la hora de alabar al alcahuete constituya una muestra de que Cervantes entendió que uno de los mecanismos retóricos que sustenta la autoalabanza de Lázaro parte de la tradición del encomio en broma ${ }^{52}$.

Con todo, las pretendidas referencias al Lazarillo no acaban con el Quijote de 1605, sino que acompañan a Pasamonte en sus incursiones de 1615. Cuando se hace pasar por Maese Pedro el otrora galeote, con ayuda del mono oráculo, engaña a los habitantes de los lugares donde elige representar la historia de la libertad de Melisendra, orquestando una burla a gran escala que le reportará pingües beneficios. En tal modo de actuación Maese Pedro recuerda al buldero del tratado $\mathrm{V}$ que, en connivencia con el alguacil corrupto,

\footnotetext{
${ }^{50}$ C. Colahan y A. Rodríguez, "Parodic alteration of the Picaresque in Cervantes' Ginés de Pasamonte/Ginesillo de Paradilla", The Modern Language Review, LXXXV (1990), pp. 609-11 y A. Rodríguez y F. Schlumbom, "Ginés de Pasamonte/Genesillo de Parapilla/Maese Petro: La barroca transformación del pícaro", Romanische Forschungen, 102, 4 (1990), pp. 438-42.

51 "Que yo juraré sobre la hostia consagrada, que es tan buena mujer como vive dentro de las puertas de Toledo. Y quien otra cosa me dijere, yo me mataré con él. De esta manera no me dicen nada, y yo tengo paz en mi casa" (134-135).

${ }^{52}$ Es la perspectiva desde la que planteo mis Razones retóricas para el Lazarillo. Teoría y práctica de la paradoja, Madrid, Biblioteca Nueva, 2002.
} 
embauca a las pobres gentes de Toledo para desplumarlas con las ventas de las bulas ${ }^{53}$. Sólo transcribiré la narración que hace Cide Hamete de las industrias del taimado titiritero:

$[\ldots]$ antes que entrase en el lugar donde entraba con su retablo y mono, se informaba en el lugar más cercano, o de quien él mejor podía, qué cosas particulares hubiesen sucedido en el tal lugar, y a qué personas; y llevándolas bien en la memoria, lo primero que hacía era mostrar su retablo, el cual unas veces era de una historia y otras de otra, pero todas alegres y regocijadas y conocidas. Acabada la muestra, proponía las habilidades de su mono, diciendo al pueblo que adivinaba todo lo pasado y lo presente, pero que en lo de por venir no se daba maña. Por la respuesta de cada pregunta pedía dos reales, y de algunas hacía barato, según tomaba el pulso a los preguntantes; y como tal vez llegaba a las casas de quien él sabía los sucesos de los que en ella moraban, aunque no le preguntasen nada por no pagarle, él hacía la seña al mono y luego decía que le había dicho tal y tal cosa, que venía de molde con lo sucedido. Con esto cobraba crédito inefable, y andábanse todos tras él. Otras veces, como era tan discreto, respondía de manera que las respuestas venían bien con las preguntas; y como nadie le apuraba ni apretaba a que dijese cómo adevinaba su mono, a todos hacía monas, y llenaba sus esqueros (856).

Sea como fuere, en Cervantes los recuerdos del Lazarillo no se circunscriben al Quijote. En diversa medida, están presentes en Rinconete y Cortadillo ${ }^{54} \mathrm{o}$ en El licenciado Vidriera $^{55}$. El escritor mantiene una visión polémica respecto a la novela picaresca, representada en concreto por su libro de más éxito, el Guzmán de Alfarache; pero, al mismo tiempo, siente una predilección por el Lazarillo, obra que no participa de todos los inconvenientes que le achaca al canon picaresco. Todo podría deberse a una rivalidad literaria. De hecho, la obra de Alemán era en esos tiempos un éxito de ventas, un libro actual y referencia obligada de lectura y crítica. El Lazarillo, sin embargo, por anónimo y con más de medio siglo de antigüedad a sus espaldas ${ }^{56}$, resultaba más inofensivo, aunque no menos magistral. Tal vez por eso se decida a nombrarlo y a homenajearlo sin ambages con un socarrón: "mal año para Lazarillo de Tormes".

\footnotetext{
53 "En entrando en los lugares do habían de presentar la bula, primero presentaba a los clérigos o curas algunas cosillas, no tampoco de mucho valor ni substancia: una lechuga murciana, si era por el tiempo; un par de limas o naranjas; un melocotón; un par de duraznos; cada sendas peras verdiniales. Ansí procuraba tenerlos propicios, porque favoreciesen su negocio y llamasen sus feligreses a tomar la bula, ofreciéndosele a él las gracias. Informábase de la suficiencia de ellos. Si decían que entendían, no hablaba en latín, por no dar tropezón; mas aprovechábase de un gentil y bien cortado romance y desenvoltísima lengua. Y si sabían que los dichos clérigos eran de los reverendos (digo, que más con dineros que con letras, y con reverendas se ordenan), hacíase entre ellos un santo Tomás y hablaba dos horas en latín. A lo menos, que lo parecía, aunque no lo era" (112-114).

${ }^{54}$ García, art. cit., p. 116.

${ }^{55}$ M. Gerli, "La picaresca y el Licenciado Vidriera: género y contragénero en Cervantes", en La picaresca. Orígenes, textos y estructuras, ed. M. Criado de Val, Madrid, FUE, 1979, pp. 577-587.

${ }^{56}$ Lo sugiere Redondo, art. cit., p. 255.
} 
